\title{
Effects of the dominant SW Atlantic intertidal burrowing crab Chasmagnathus granulatus on sediment chemistry and nutrient distribution
}

\author{
Eugenia Fanjul $^{1, *}$, María A. Grela ${ }^{2}$, Oscar Iribarne ${ }^{1}$ \\ ${ }^{1}$ Departamento de Biología (FCEyN) (CONICET), Universidad Nacional de Mar del Plata, CC 573 Correo Central, \\ B7600WAG, Mar del Plata, Argentina \\ ${ }^{2}$ Departamento de Química (FCEyN) (CONICET), Universidad Nacional de Mar del Plata, Funes 3350, Mar del Plata, \\ Argentina
}

\begin{abstract}
Through field experiments and chemical analysis of the sediment and pore water, we investigated the effect of the burrowing crab Chasmagnathus granulatus on the distribution and availability of electron acceptors in mudflat sediments. The results show that the presence and activity of $C$. granulatus and its burrows determine the chemical characteristics of pore water and the redox state of mudflat sediments. Crabs enhance the transport of particulate material in the sediment column, completely mixing the upper $7 \mathrm{~cm}$ of sediment in a few days. Comparative analyses of pore water from areas (1) with crabs and burrows, (2) with unoccupied burrows, and (3) without burrows or crabs reveal a large increase in sediment oxygenation, modification of pore water salinity and the distribution of dissolved inorganic nitrogen and sulphate when crabs are present. Denitrification and organic matter (OM) degradation rates were estimated by a diagenetic model that searches for simultaneous agreement between measured and model-calculated depth profiles. OM degradation rates $(\mathrm{kG})$ were found to be greater in bioturbated $\left(\mathrm{kG}=10.6 \pm 6.1[\mathrm{SD}] \mu \mathrm{M} \mathrm{s}{ }^{-1}\right)$ than in non-bioturbated sediments $\left(\mathrm{kG}=4.9 \pm 17.8 \mu \mathrm{M} \mathrm{s}^{-1}\right.$ if unoccupied burrows were present; $\mathrm{kG}=0.02 \pm 0.013 \mu \mathrm{M}$ $\mathrm{s}^{-1}$ without burrows). Model-estimated denitrification rates revealed that OM degradation pathways are also affected by $C$. granulatus activities and their burrows. These changes in the sediment chemistry that are directly and indirectly produced by C. granulatus could comprise the force that drives the pathways of microbial processes and nutrient flows to neighbouring systems.
\end{abstract}

KEY WORDS: Biogeochemistry · Bioturbation · Chasmagnathus granulatus $\cdot$ Intertidal sediments

\section{INTRODUCTION}

Estuaries are among the most productive marine ecosystems of the world (e.g. Alongi 1998). Intertidal areas of estuaries are productive and dynamic systems with extreme and variable environmental conditions (Alongi 1998). The high rates of transformation of different elements (e.g. N, P, S) from organic to inorganic forms during mineralization and assimilation are their main biogeochemical processes (Rozema et al. 2000). The periodic and predictable flood produced by tides affects interstitial water levels and chemistry (Alongi 1998). Tides act in antagonistic form, and the sedi- ments of salt marshes are subject to daily changes in their state of aeration. During the high tide, sediment is flooded, promoting anaerobic processes; in contrast, during ebb tide, it is drained, the salt excess is removed and sediment surface layers attain high redox potentials (Schlesinger 1991). These oscillations in the redox state may affect not only energy and nutrient flows but also the rates and pathways of organic matter (OM) degradation (Alongi 1998).

In shallow coastal waters and estuaries, OM decomposition occurs mainly in sediments (Nedwell et al. 1999). The incorporation of particulate OM into bottom sediments and its consequent mineralization may be 
mediated by the activity of meio- and macrofauna (Herman et al. 1999). These organisms can affect sediment chemistry by tube-building, bioturbation, defecation, respiration and mucus secretion (Alongi 1998, Kostka et al. 2002). However, mineralization of OM requires the supply of electron acceptors to drive the predominantly microbial oxidation (Nedwell et al. 1999). Thus, electron acceptors are a limiting resource in most non-bioturbated sediments given that oxygen penetration, and therefore the aerobic processes of decomposition, are restricted to the uppermost millimeters of sediment (Revsbech et al. 1980) and the deeper layers are characterized by anaerobic decomposition processes (e.g. Kostka et al. 2002). Kostka et al. (2002) showed that both invertebrate macrofauna and macrophyte plants affect microbial sediment metabolism. They found that pore water constituents at bioturbated unvegetated areas were more similar to non-bioturbated unvegetated areas than to bioturbated vegetated areas. Thus, bioturbation activities and plant roots (Kostka et al. 2002) can increase the depth of the sediment oxic layer, favoring aerobic processes.

The SW Atlantic embayment and estuarine intertidal environments are dominated by the burrowing activity of the crab Chasmagnathus granulatus. This relatively large crab (up to $40 \mathrm{~mm}$ carapace width; Boschi 1964) is distributed from southern Brazil $\left(23^{\circ} \mathrm{S}\right)$ to the northern Argentinean Patagonia (San Matías Gulf, $41^{\circ} \mathrm{S}$; Boschi 1964). This crab inhabits the intertidal, from mudflats to marsh areas vegetated by Spartina densiflora, Sarcocornia perennis and Juncus acutus (Boschi 1964, Botto et al. 2005, Bortolus 2006). It dominates the intertidal soft-bottom sediments, generating extensive burrowing beds where burrow density may reach up to 60 burrows $\mathrm{m}^{-2}$ (Iribarne et al. 1997, Botto \& Iribarne 2000). Satellite images and landscape measurements show that crab beds covered most of the intertidal areas of estuaries and embayments of this region (e.g. Bahía Blanca Estuary, 38 48' S, area $\approx 110000$ ha; Mar Chiquita coastal lagoon, $37^{\circ} 46^{\prime} \mathrm{S}$, area $\approx 4500 \mathrm{ha}$; see Iribarne et al. 2005, Botto et al. 2006). Burrows are large (up to $17 \mathrm{~cm}$ width and $1 \mathrm{~m}$ depth) and semipermanent with high rates of sediment excavation (between $2.5 \mathrm{~kg} \mathrm{~m}^{-2}$ in the salt marsh and $6 \mathrm{~kg} \mathrm{~m}^{-2}$ in the tidal flat; Iribarne et al. 1997, Botto \& Iribarne 2000). Crabs are primarily deposit feeders in mud flats and herbivorous-detritivorous in the salt marsh (Iribarne et al. 1997, Botto et al. 2005). In the mud flats, their relatively short burrows (up to $40 \mathrm{~cm}$ depth) with funnel-shaped entrances (see Iribarne et al. 1997) affect the particle movement and near-bottom fluid dynamics, working as passive traps of sediments and OM (Botto et al. 2005, 2006) and detritus (Iribarne et al. 2000, Botto et al. 2006). Thus, all evidence suggests that burrows reduce the OM export from the salt marshes towards the open coast or estuarine waters (Iribarne et al. 1997, Botto \& Iribarne 2000, Botto et al. 2006). In the salt marsh, crabs construct vertical straight tubular burrows of up to $1 \mathrm{~m}$ depth (up to $40 \mathrm{~mm}$ diameter), generally reaching the water table (Iribarne et al. 1997, Bortolus et al. 2002). Crabs have direct and indirect ecological effects at an ecosystem scale: they indirectly affect the habitat selection and foraging rates of migratory shorebirds by changing prey availability (Escapa et al. 2004), and also affect the habitat use of fishes, zooplankton (Martinetto et al. 2005) and other crabs during the high tide (Iribarne et al. 2005).

Most evidence also suggests that Chasmagnathus granulatus has an important effect on the particle redistribution (Botto \& Iribarne 2000), sediment chemistry (Botto et al. 2005, Gutiérrez et al. 2006), drainage (Iribarne et al. 1997, Botto \& Iribarne 2000) and sediment oxygenation (Botto et al. 2005, Gutiérrez et al. 2006). Although these effects have not yet been directly evaluated, crab bioturbation is expected to affect sediment oxygenation and therefore the rates and pathways of $\mathrm{OM}$ mineralization and the dynamics of nutrients. In this context, the main goal of this study was to evaluate whether the burrowing crab $C$. granulatus affects the distribution and availability of nutrients (in particular electron acceptors) and the oxygenation of intertidal sediments. Thus, we tested the general hypothesis that the crabs affect sediment chemistry characteristics through bioturbation and defecation activities in their burrows, and also by the increase of sediment surface area brought about by the addition of the burrow walls. Using field sampling and experiments we evaluated these 2 possible mechanisms.

\section{MATERIALS AND METHODS}

Study site. The study was performed at the Mar Chiquita Coastal Lagoon, Argentina ( $\left.37^{\circ} 46^{\prime} \mathrm{S}, 57^{\circ} 27^{\prime} \mathrm{W}\right)$, a brackish water body (salinity range 0 to 43 ), affected by low amplitude tides (up to $1.5 \mathrm{~m}$ ) and characterized by soft bottoms (Fasano et al. 1982, Iribarne et al. 1997). The study was conducted between November 2004 and October 2005.

Effects of Chasmagnathus granulatus burrows on the sediment-water interface. Density of burrows of C. granulatus were sampled in 7 different intertidal zones defined by differences in inundation times (4 levels in the marsh and 3 levels in the mudflat; $n=10$ for each level, $0.25 \mathrm{~m}^{2}$ ) in October 2005. Based on previous work (see Iribarne et al. 1997, Bortolus et al. 2002) we assumed a burrow depth of $1 \mathrm{~m}$ in the high 
marsh to $0.4 \mathrm{~m}$ in the low marsh with intervals of $0.2 \mathrm{~m}$; for the 3 levels in the mudflat we used a depth of $0.4 \mathrm{~m}$. Considering the burrow density across the intertidal area, mean diameter $(3.6 \mathrm{~cm}$; Iribarne et al. 1997, Botto \& Iribarne 2000), burrow depth, and assuming straight tube shapes (Iribarne et al. 1997), the sediment volume not occupied by burrows per $\mathrm{m}^{3}$ of sediment and the increase in sediment-air exchange area (surface area) generated by burrows were calculated across the intertidal area. Also, the ratio between the enhancement of sediment-air exchange area and the volume of sediment occupied by burrows in each zone was calculated as an indicator of positive effects (i.e. maximizing sediment-water exchange area and the sediment availability). The Kruskal-Wallis test (Zar 1999) was used to evaluate the null hypothesis $\left(H_{0}\right)$ of no difference in the density of burrows, volume of sediment not occupied by burrows and exchange area between intertidal zones.

Pore water characteristics at bioturbated and nonbioturbated natural areas. Mudflat areas were sampled to evaluate if there are differences in pore water characteristics within natural areas with and without crabs. In the 'crab bed' (zones with high densities of crabs; more than 30 burrows $\mathrm{m}^{-2}$ ) vertical sediment samples (from the burrow wall up to $3 \mathrm{~cm}$ from the burrow, $\mathrm{n}=5$ ) and radial samples around the burrow ( 3 to $5 \mathrm{~cm}$ depth, $\mathrm{n}=5$ ) were taken. In the 'bare' areas (zones without crabs) only vertical sediment samples $(\mathrm{n}=5)$ were taken. Sediment samples to determine chloride $\left(\mathrm{Cl}^{-}\right)$, sulphate $\left(\mathrm{SO}_{4}{ }^{2-}\right)$, nitrate $\left(\mathrm{NO}_{3}{ }^{-}\right)$, ammonium $\left(\mathrm{NH}_{4}{ }^{+}\right)$and $\mathrm{Fe}^{2+} / \mathrm{Fe}^{3+}$ were collected by gently pushing a PVC core $(3 \mathrm{~cm}$ diameter, $20 \mathrm{~cm}$ length) into the sediment. Cores were immediately transported to the laboratory and sectioned into $0-0.5,0.5-1.5,1.5-3$, $3-5,5-7$ and $7-10 \mathrm{~cm}$ intervals (of depth or distance from the burrow wall, according to whether they were vertical or radial samples). Pore water was obtained by centrifugation $(9000 \times g$ for $10 \mathrm{~min})$, and was then filtered and stored at $-20^{\circ} \mathrm{C}$ until analysis. Sediment sectioning and manipulation was carried out under air atmosphere within $6 \mathrm{~h}$ of obtaining the sample.

Effect of Chasmagnathus granulatus activities on pore water and sediment characteristics. A manipulative field experiment was performed to evaluate if there is a direct effect of $C$. granulatus on the content and distribution of nutrients and other dissolved solutes in sediment pore water, and on sediment oxygenation. The experiment was deployed in a line parallel to the tidal line at the marsh edge (outside the marsh). It consisted of 2 treatments: (1) inclusion of adult C. granulatus in artificially constructed burrows (hereafter $\mathrm{C}+\mathrm{B}$ ); and (2) exclusion of crabs to act as 'control' treatments without effects of crabs or burrows (hereafter NBC). All experimental boxes were placed in areas without burrows and not inhabited by crabs in order to evaluate their actual effects on the sediment. Both treatments consisted of boxes $(80 \mathrm{~cm}$ side; 4 replicates in each treatment) with lateral walls of solid PVC ( $80 \mathrm{~cm}$ wide $\times 70 \mathrm{~cm}$ high) buried into the sediment at $70 \mathrm{~cm}$ depth. The lateral walls continued $40 \mathrm{~cm}$ above the sediment surface with plastic mesh (opening $0.5 \mathrm{~cm}$ ) to include $(\mathrm{C}+\mathrm{B})$ or exclude $(\mathrm{NBC})$ adult crabs in the different boxes. Notice that pore water lateral infiltration from the exterior sediment of the boxes was reduced to a minimum in this setup.

Previous experiments comparing sediments without crabs or burrows, with and without plastic walls, showed no differences between unboxed and boxed controls for any measured variable (E. Fanjul unpubl. data). Artificially constructed burrows $(30 \mathrm{~cm}$ depth; 30 burrows $\mathrm{m}^{-2}$ ) were generated by pushing a PVC pipe ( $3 \mathrm{~cm}$ diameter) into sediments. Artificial burrows allow pore water exchange though the burrow wall because they do not have any kind of mesh. One adult crab per burrow was added to each $\mathrm{C}+\mathrm{B}$ treatment, and boxes were periodically observed to ensure that crabs were alive and active in $\mathrm{C}+\mathrm{B}$ plots, and to check that crabs did not colonize the control plots (when a crab was found in these plots, it was removed by hand). This experiment was sampled after $90 \mathrm{~d}$ (from November 2004 to February 2005) to ensure a minimum sediment disturbance resultant from sediment manipulation activities during the set up. Both vertical (from burrow wall to $3 \mathrm{~cm}$ distance to burrow) and radial (from 3 to $6 \mathrm{~cm}$ depth) sediment samples were taken in $\mathrm{C}+\mathrm{B}$ treatments; vertical samples were taken in NBC. To reduce border effects, samples were taken from the central area of each box. Sediment samples were collected and manipulated as described above. The $H_{0}$ (no crab effect) in the measured variables for vertical profiles between different treatments and among depth strata was evaluated by 2-way ANOVA (Zar 1999). When a significant interaction was found, main effects of factors were not considered owing to the lack of independence between them (Underwood 1997). A posteriori multiple comparison tests (Least Significant Difference tests, LSD) were performed when significant differences between factors were found (Underwood 1997). The $H_{0}$ (no crab effect) in measured variables for radial profiles among the different distances to burrow wall was evaluated using 1-way ANOVA.

Effect of Chasmagnathus granulatus burrows on pore water and sediment characteristics. A field experiment was deployed to discriminate effects of crab activities and burrows from effects of burrows without crabs (direct and indirect effects). Identical boxes to those used in the previous experiment $(n=12)$ were constructed to evaluate these direct and indirect effects on pore water characteristics. The experiment was 
placed in the same intertidal area as in the previous experiment, and consisted of 3 treatments: (1) inclusion of adult crabs C. granulatus in artificially constructed burrows (hereafter $\mathrm{C}+\mathrm{B}$ ); (2) unoccupied artificially constructed burrows (hereafter B); and (3) exclusion of crabs and of burrows to act as a 'control' treatment without effect of crabs or burrows (NBC). The 'burrow' treatment was performed to exclude effects of crabs that inhabited artificially constructed burrows inside the experimental boxes, obtaining unoccupied artificial burrows. Vertical samples (from burrow to $3 \mathrm{~cm}$ distance to burrow) were taken in $\mathrm{C}+\mathrm{B}, \mathrm{B}$ and $\mathrm{NBC}(\mathrm{n}=4$ each treatment) treatments. Samples were taken and manipulated as described above. The $H_{0}$ (no crab effect) in the measured variables between treatments and depths was evaluated by 2-way ANOVA (Zar 1999).

Effect of Chasmagnathus granulatus on the transport of particulate material in the sediment column. To evaluate the effect of the activity of $C$. granulatus on the particle transport, a field experiment was performed by adding glass microspheres (particle size 20 to $70 \mu \mathrm{m}$ ) onto the sediment surface. Exclusion boxes $(\mathrm{n}=5)$ were constructed from plastic mesh (circular boxes, $50 \mathrm{~cm}$ diameter and $20 \mathrm{~cm}$ height) with a cover of the same material ('no-crab' treatment). Identical boxes, but without covers, were constructed to allow the free access of crabs ('crab' treatment). A surface sediment layer $(1 \mathrm{~cm}$ depth) was extracted from all boxes, mixed with the same volume of glass microspheres and replaced on the sediment surface in experimental boxes. After $30 \mathrm{~d}$, vertical sediment samples were taken and divided over the same depth intervals as for pore water analysis. Sediment-sliced samples were dried, weighed and treated with $20 \mathrm{ml}$ $5 \%$ hydrogen peroxide for $48 \mathrm{~h}$ to remove OM. Samples were stirred and 10-drop subsamples were mixed with 10 drops of $30 \%$ glycerol (to facilitate microsphere suspension) and mounted on slides. Sediment microspheres were quantified by counting microspheres under a light microscope at $40 \times$ magnification. The $H_{0}$ (no crab effect) on the microsphere content among different treatments and depth strata was evaluated by 2-way ANOVA (Zar 1999).

To quantify bioturbation intensity (i.e. intensity of vertical particle displacement), bioturbation coefficients $\left(D_{\mathrm{B}}\right)$ were estimated for each treatment by analyzing the observed gradients of glass microspheres following Wheatcroft's (1992) procedure for a nondecaying particulate tracer. The experimental profiles were simulated by iteratively solving the theoretical curve (see Wheatcroft 1992) using different $D_{\mathrm{B}}$ values, which were assumed to be depth-independent. The adopted values of $D_{\mathrm{B}}$ were those that yielded the smallest median residual. The $H_{0}$ (no crab effect) on $D_{\mathrm{B}}$ among treatments was evaluated by $t$-test (Zar 1999).
Effect of crabs on OM remineralization. To quantify the rates and pathways of OM remineralization, the 1-dimensional inverse diagenetic model formulated by Furukawa et al. (2004) was applied to the Mar Chiquita sediments using the experimental depth profile data. The inverse model determines OM degradation rates by searching for simultaneous agreement between measured and model-calculated depth profiles of electron acceptor concentrations. The geochemical species considered were $\mathrm{O}_{2}, \mathrm{SO}_{4}{ }^{2-}, \mathrm{NO}_{3}{ }^{-}$and $\mathrm{NH}_{4}{ }^{+}$. Reaction rate expressions and net production rates of geochemical species were taken from Berg et al. (2003). Parameters required for the inverse modelling are listed in Table 1. Some were determined through direct measurements made during the field study and others taken from previous work (see Table 1). The bioturbation coefficient was obtained as previously described. The irrigation coefficient $(\alpha)$ was estimated assuming cylindrical burrows of $1 \mathrm{~m}$ depth (Iribarne et al. 1997) following Koretsky et al. (2002). For this estimate, radial $\mathrm{O}_{2}$ concentration was calculated from Eh and $\mathrm{pH}$ radial profiles. All pore water species were assigned the same $\alpha$. Molecular diffusion coefficients at infinite dilution $\mathrm{D}_{\mathrm{O}}$ were taken from Furukawa et al. (2004) and corrected for sediment porosity $\varphi$ (see Table 1). Model calculations were performed using 100 sets of randomized initial values for $\mathrm{OM}$ degradation rate (for each $\mathrm{C}+\mathrm{B}, \mathrm{B}$ and $\mathrm{NBC}$ treatment) to ensure that optimization leads to a global minimum. It should be stressed that, in contrast with other reports, our procedure involves only 1 adjustable parameter, total OM degradation rate $(\mathrm{kG})$, because all others required in the calculations were independently obtained or taken from the literature. The agreement between measured and model-calculated depth profiles (not shown in the figures for simplicity) was within experimental errors (typically $10 \%$ ) for all species.

A model was used to determine the depth profiles of kG and OM degradation rate by each electron acceptor (i.e. oxygen, nitrate and sulphate) according to the formulae given by Furukawa et al. (2004) and Meysman et al. (2005). The oxygen, nitrate and sulphate consumption rates resulting from OM remineralization were calculated according to the reaction stoichiometry (see Berg et al. 2003). Once consumption rates were estimated, depth-integrated electron acceptor usage for the upper $10 \mathrm{~cm}$ of sediments was calculated for each treatment.

Pore water and sediment analyses. Chloride $\left(\mathrm{Cl}^{-}\right)$, sulphate $\left(\mathrm{SO}_{4}{ }^{2-}\right)$, nitrate $\left(\mathrm{NO}_{3}{ }^{-}\right)$, ammonium $\left(\mathrm{NH}_{4}{ }^{+}\right)$and iron $\left(\mathrm{Fe}^{2+}\right.$ and $\left.\mathrm{Fe}^{3+}\right)$ concentrations and $\mathrm{pH}$ were measured in the pore water. Chloride was measured as salinity by refractometry. Sulphate and nitrate were analyzed after the elimination of $\mathrm{Cl}^{-}$by ion-chromatography (Universal Anion column $150 \mathrm{~mm}, \mathrm{HCO}_{3}{ }^{-} / \mathrm{CO}_{3}{ }^{2-}$, 
Table 1. Chasmagnathus granulatus. Crab bioturbation experiments. Inverse model parameters for C+B (crabs + artificial burrows), B (burrows only) and NBC (no crabs or burrows) experimental treatments

\begin{tabular}{|c|c|c|c|c|}
\hline \multirow[t]{2}{*}{ Parameter } & \multicolumn{3}{|c|}{ _Values } & \multirow{2}{*}{ Description/source } \\
\hline & $\mathrm{C}+\mathrm{B}$ & B & NBC & \\
\hline $\begin{array}{l}\text { Burrow density } \\
\text { (burrow } \mathrm{m}^{-2} \text { ) }\end{array}$ & 30 & 30 & 0 & \\
\hline Burrow radius (m) & 0.018 & 0.018 & & Iribarne et al. (1997), Botto \& Iribarne (2000) \\
\hline$\rho\left(\mathrm{g} \mathrm{cm}^{-3}\right)$ & 1.72 & 1.72 & 1.77 & Sediment density (E. Fanjul unpubl. data) \\
\hline $\mathrm{C} / \mathrm{N}$ ratio & 19.5 & 19.5 & 19.5 & F. Botto (unpubl. data) \\
\hline$D_{\mathrm{B}}\left(\mathrm{m}^{2} \mathrm{~s}^{-1}\right)$ & $7.8 \times 10^{-10}$ & $1.14 \times 10^{-10}$ & $1.14 \times 10^{-10}$ & Bioturbation coefficients (this study) \\
\hline$\alpha\left(\mathrm{s}^{-1}\right)$ & $1.06 \times 10^{-7}$ & 0 & 0 & Irrigation coefficient \\
\hline$\omega\left(\mathrm{cm} \mathrm{yr}^{-1}\right)$ & 0.01 & 0.01 & 0.01 & Sedimentation rate \\
\hline$D_{\text {net }}^{\mathrm{O}_{2}}\left(\mathrm{~m}^{2} \mathrm{~s}^{-1}\right)$ & $1.23 \times 10^{-9}$ & $5.69 \times 10^{-10}$ & $5.5 \times 10^{-10}$ & Net diffusion coefficient $\left(D_{\mathrm{S}}+D_{\mathrm{B}}\right) . D_{\mathrm{S}}$ is the \\
\hline$D_{\mathrm{net}^{\mathrm{N}}}^{\mathrm{NO}^{-}}\left(\mathrm{m}^{2} \mathrm{~s}^{-1}\right)$ & $1.17 \times 10^{-9}$ & $5 \times 10^{-10}$ & $4.84 \times 10^{-10}$ & tortuosity-corrected molecular diffusion coeffi- \\
\hline$D_{\mathrm{net}^{+}}^{\mathrm{NH}_{4}^{+}}\left(\mathrm{m}^{2} \mathrm{~s}^{-1}\right)$ & $1.18 \times 10^{-9}$ & $5.13 \times 10^{-10}$ & $4.97 \times 10^{-10}$ & cient: $D_{\mathrm{S}}=\frac{D_{\mathrm{O}}}{1-2 \ln \varphi^{2}} \quad($ Boudreau 1997) \\
\hline$D_{\text {net }^{2-}}^{\mathrm{SO}^{2-}}\left(\mathrm{m}^{2} \mathrm{~s}^{-1}\right)$ & $2.22 \times 10^{-8}$ & $2.15 \times 10^{-8}$ & $2.06 \times 10^{-8}$ & \\
\hline$K_{\mathrm{NO}_{3}^{\prime}}^{-} K_{\mathrm{NO}_{3}^{-}}^{\prime}$ & $8 \times 10^{-6}$ & $8 \times 10^{-6}$ & $8 \times 10^{-6}$ & Monod constants (Boudreau et al. 1998) \\
\hline$K_{\mathrm{O}_{2^{\prime}}} K_{\mathrm{O}_{2}}^{\prime}$ & $3 \times 10^{-5}$ & $3 \times 10^{-5}$ & $3 \times 10^{-5}$ & \\
\hline$K_{\mathrm{SO}_{4}^{2-}}, K_{\mathrm{SO}_{4}^{2-}}^{\prime 2-}$ & 0.001 & 0.001 & 0.001 & \\
\hline$K_{\mathrm{N}}$ & 1.4 & 1.4 & 1.4 & N adsorption constant (Mackin \& Aller 1984) \\
\hline$k_{6}\left(1 \mathrm{~mol}^{-1} \mathrm{~s}^{-1}\right)$ & $6.3 \times 10^{-1}$ & $6.3 \times 10^{-1}$ & $6.3 \times 10^{-1}$ & $\begin{array}{l}\text { Rate constant for ammonium oxidation with } \mathrm{O}_{2} \\
\text { (Berg et al. 2003) }\end{array}$ \\
\hline$\left[\mathrm{O}_{2}\right]\left(\mathrm{mol} \mathrm{l}^{-1}\right)$ & $1.5 \times 10^{-4}$ & $1.5 \times 10^{-4}$ & $1.5 \times 10^{-4}$ & Concentrations at water-sediment interface \\
\hline$\left[\mathrm{NO}_{3}{ }^{-}\right]\left(\mathrm{mol} \mathrm{l}^{-1}\right)$ & $5 \times 10^{-6}$ & $5 \times 10^{-6}$ & $5 \times 10^{-6}$ & (E. Fanjul unpubl. data) \\
\hline$\left[\mathrm{NH}_{4}^{+}\right]\left(\mathrm{mol} \mathrm{l}^{-1}\right)$ & $4 \times 10^{-5}$ & $4 \times 10^{-5}$ & $4 \times 10^{-5}$ & \\
\hline$\left[\mathrm{SO}_{4}{ }^{2-}\right]\left(\mathrm{mol} \mathrm{l}^{-1}\right)$ & 0.02 & 0.02 & 0.02 & \\
\hline
\end{tabular}

mobile phase 1.25/0.85 mM, suppressed conductivity detection). $\mathrm{NH}_{4}{ }^{+}$was measured by the blue-indophenol method (Solórzano 1969). $\mathrm{Fe}^{2+}$ and $\mathrm{Fe}^{3+}$ were measured by the 1,10-phenantroline method (Tamura 1974) before and after treatment with $1 \mathrm{M}$ hydroxylamine hydrochloride. Solid-phase iron (Fe[II] and Fe[III]) was determined in the sediment pellets immediately after centrifugation. Iron was extracted in $0.5 \mathrm{M}$ $\mathrm{HCl}$ for $1 \mathrm{~h}$ under $\mathrm{N}_{2}$ atmosphere (HCl-extractable $\mathrm{Fe}$ ) and analyzed with the 1,10-phenantroline method.

Sediment redox potential (Eh) vertical and radial profiles for each experimental treatment $(n=5)$ were measured in situ with a combined Pt electrode with $\mathrm{Ag} / \mathrm{AgCl}$ internal reference. Obtained values were corrected with respect to a reference hydrogen electrode.

\section{RESULTS}

\section{Effects of Chasmagnathus granulatus burrows on sediment-water interface}

Burrow density differed across the different intertidal levels, with the highest values in the medium- and low-marsh and the lowest values in the medium- and low-mudflat (Kruskal-Wallis: $H_{6,70}=55.33, \mathrm{p}<0.001$; Fig. 1A). The volume of sediment not occupied by burrows was larger at the medium- and low-mudflat and at the high marsh than in the other intertidal levels (Kruskal-Wallis: $H_{6,70}=50.15, \mathrm{p}<0.001$; Fig. 1B). The sediment-water exchange area differed across the intertidal zones, with the lowest values in the mediumand low-mudflat and in the high-marsh (KruskalWallis: $H_{6,70}=50.23, \mathrm{p}<0.001$; Fig. 1C).

\section{Pore water characteristics in natural areas}

Salinity was higher at surface sediments at the 2 sites, showing interaction effects between site and depth $\left(\right.$ Site $\times$ Depth: $F_{5,48}=4.10, \mathrm{p}<0.05$; Fig. 2A). The sulphate concentration in surface sediment was similar for crab bed and bare sites (mean $\pm \mathrm{SD}=62.59 \pm$ $12.4 \mathrm{mM}, \mathrm{n}=5 ; 60.33 \pm 8.56 \mu \mathrm{M}, \mathrm{n}=5$, respectively), but in deeper sediment higher concentrations were found at crab bed sites (Site $\times$ Depth: $F_{5,48}=2.74$, $\mathrm{p}<0.05$; Fig. 2B). Significant interaction was found for nitrate concentrations (Site $\times$ Depth: $F_{5,48}=2.48$, $\mathrm{p}<0.05$; Fig. 2C). Nitrate profiles with crabs present the maximum concentration at 0.5 to $1.5 \mathrm{~cm}$ depth. Depth-integrated nitrate concentration was higher in 
the crab bed than at bare sites (mean $\pm \mathrm{SD}=15.59 \pm$ $8.05 \mu \mathrm{M}, \mathrm{n}=30 ; 12.80 \pm 5.70 \mu \mathrm{M}, \mathrm{n}=30$, respectively). Without crabs, ammonium showed a low level at all depths, while at sites with crabs, ammonium attained the maximum concentration between 3 and $4 \mathrm{~cm}$ (Site $\times$ Depth: $F_{5,48}=10.67, \mathrm{p}<0.05$; Fig. 2D). Dissolved iron content was smaller than our detection limit $(1 \mu \mathrm{M})$. The $\mathrm{Fe}(\mathrm{II}) / \mathrm{Fe}(\mathrm{II}+\mathrm{III})$ ratio showed interaction effects between factors (Site $\times$ Depth: $F_{5,48}=8.07, \mathrm{p}<0.05$ ). At the bare sites, this ratio exhibited a maximum value between 2 and $3 \mathrm{~cm}$ depth; in contrast, at the crab bed sites, the ratio values did not change significantly with depth.

Salinity around Chasmagnathus granulatus burrows showed no differences with distance to the burrow (Fig. 2E). The sulphate concentration was higher at between 0 and $1.5 \mathrm{~cm}$ distance to the burrow $\left(F_{5,24}=\right.$ 15.142, p $<0.05$; Fig. 2F). The nitrate concentration showed the highest value between 3 and $4 \mathrm{~cm}$ from the burrow $\left(F_{5,24}=5.757, \mathrm{p}<0.05\right.$; Fig. 2G). Ammonium content did not differ significantly with distance to the burrow (Fig. 2H). The Fe(II)/Fe(II + III) ratio did not change with distance to the burrow.

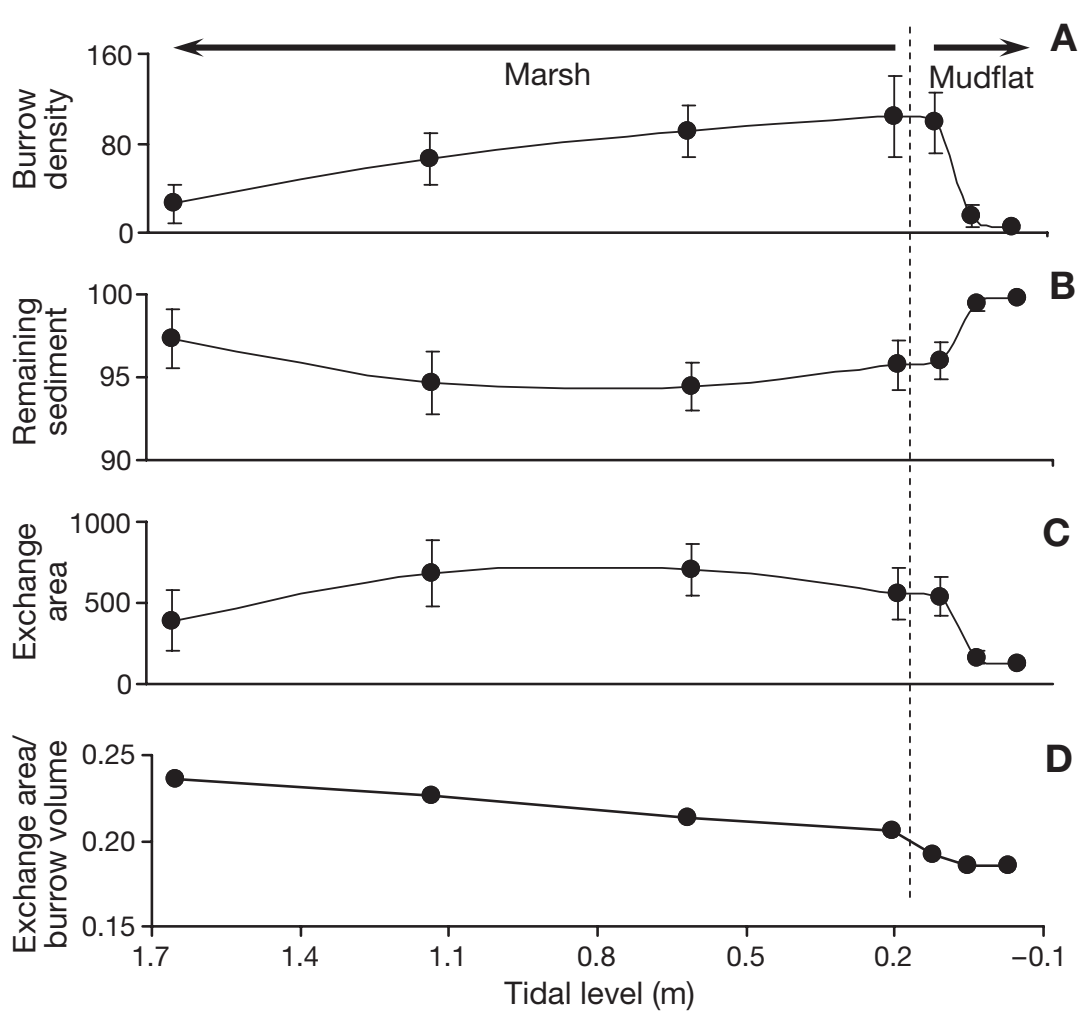

Fig. 1. Chasmagnathus granulatus. (A) Density of burrows (burrows $\mathrm{m}^{-2}$ ) across the intertidal zone; (B) volume $\left(\mathrm{m}^{3}\right)$ without burrows per $\mathrm{m}^{3}$ of sediment across the intertidal zone $(\%)$; $(\mathrm{C})$ exchange area generated by burrow presence per $\mathrm{m}^{3}$ surface area (\%); (D) ratio between exchange area and volume of sediment occupied by burrows across the intertidal zone. Vertical broken line separates areas between the mudflat and marsh

\section{Effect of Chasmagnathus granulatus activities on pore water and sediment characteristics}

Vertical profiles of pore water salinity at both treatments in the crab exclusion experiment decreased with depth (Depth: $F_{5,35}=16.15, \mathrm{p}<0.05$ ). Salinity at the surface was higher in NBC treatments than in $\mathrm{C}+\mathrm{B}$ treatments, whereas it was less in the interval of 7 to $10 \mathrm{~cm}$ (Treatment: $F_{1,35}=3.35, \mathrm{p}<0.05$; Fig. 3A). Sulphate concentration of both NBC and C+B treatments decreased with depth but showed no difference between treatments (Depth: $F_{5,35}=5.13, \mathrm{p}<0.05$; Fig. 3B). Nitrate concentration showed interaction effects between treatment and depth (Treatment $\times$ Depth: $F_{5,35}=3.00, \mathrm{p}<0.05$; Fig. 3C). The highest nitrate content was in the 2 to $3 \mathrm{~cm}$ depth interval in the $\mathrm{C}+\mathrm{B}$ treatment. However, there were no differences in the deeper layers. Significant interaction was found for ammonium concentrations (Treatment $\times$ Depth: $\left.F_{5,35}=3.73, \mathrm{p}<0.05\right)$. Ammonium concentration was lower in the non-bioturbated NBC treatment in the first 2 depth layers, while no differences were found in deeper sediment (Fig. 3D). The $\mathrm{NO}_{3}{ }^{-} /\left(\mathrm{NO}_{3}{ }^{-}\right.$ $+\mathrm{NH}_{4}^{+}$) ratio showed an interaction between treatment and depth (Treatment $\times$ Depth: $F_{5,35}=9.80, \mathrm{p}<0.05$; Fig. 4A). An a posteriori LSD test showed that this ratio was higher for NBC treatments on the surface layer. However, in the deeper layers, this ratio between oxidized and reduced compounds was higher in the bioturbated $\mathrm{C}+\mathrm{B}$ treatments. The extractable $\mathrm{Fe}(\mathrm{II}) / \mathrm{Fe}(\mathrm{II}+\mathrm{III})$ ratio showed significant interaction between the factors: this ratio was higher in the upper and deeper intervals in the bioturbated treatment, but did not show differences between treatments in the middle depth interval (Treatment $\times$ Depth: $F_{5,35}=3.81, \mathrm{p}<0.05$; Fig. 4B).

Salinity in the treatment $\mathrm{C}+\mathrm{B}$ decreased as the radial distance from the burrow increased $\left(F_{5,18}=6.417, \mathrm{p}<0.05\right.$; Fig. 5A). Sulphate concentration decreased when increasing the distance to the burrow in the first $4 \mathrm{~cm}\left(F_{5,18}=\right.$ 2.9821, $\mathrm{p}<0.05$; Fig. 5B). The nitrate content increased in the 1 to $6 \mathrm{~cm}$ interval, and remained constant between 6 and $10 \mathrm{~cm}\left(F_{5,18}=3.3926, \mathrm{p}<0.05\right.$; Fig. 5C). The ammonium concentration was higher between 2 and $5 \mathrm{~cm}$ than in the rest of the profile $\left(F_{5,18}=3.7517, \mathrm{p}<\right.$ 0.05; Fig. 5D). 

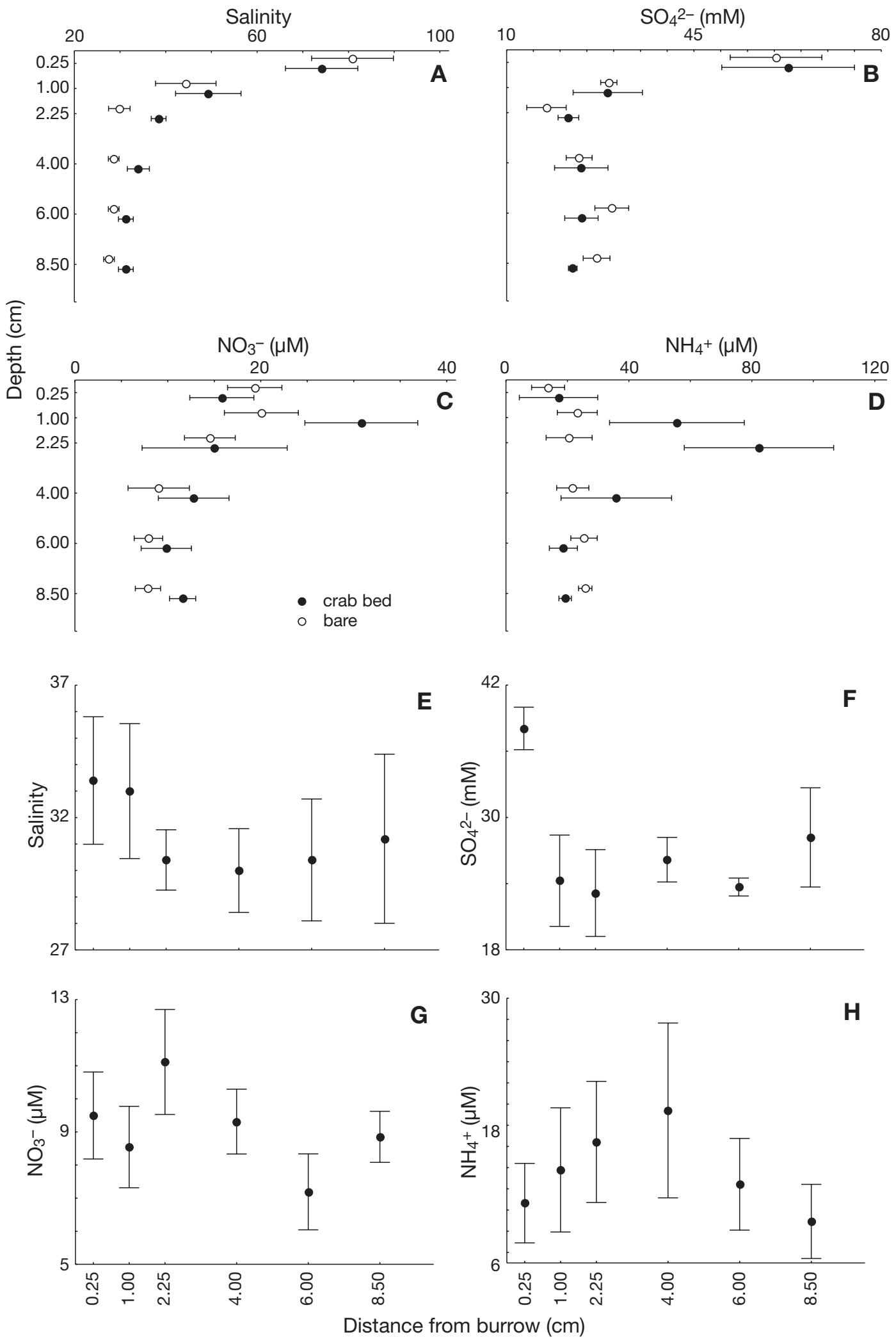

Fig. 2. Depth profiles of (A) salinity; (B) sulphate concentration; (C) nitrate concentration; and (D) ammonium concentration in the crab bed and bare areas, and radial profiles of $(\mathrm{E})$ salinity; $(\mathrm{F})$ sulphate concentration; $(\mathrm{G})$ nitrate concentration; and $(\mathrm{H})$ ammonium concentration in crab bed areas 


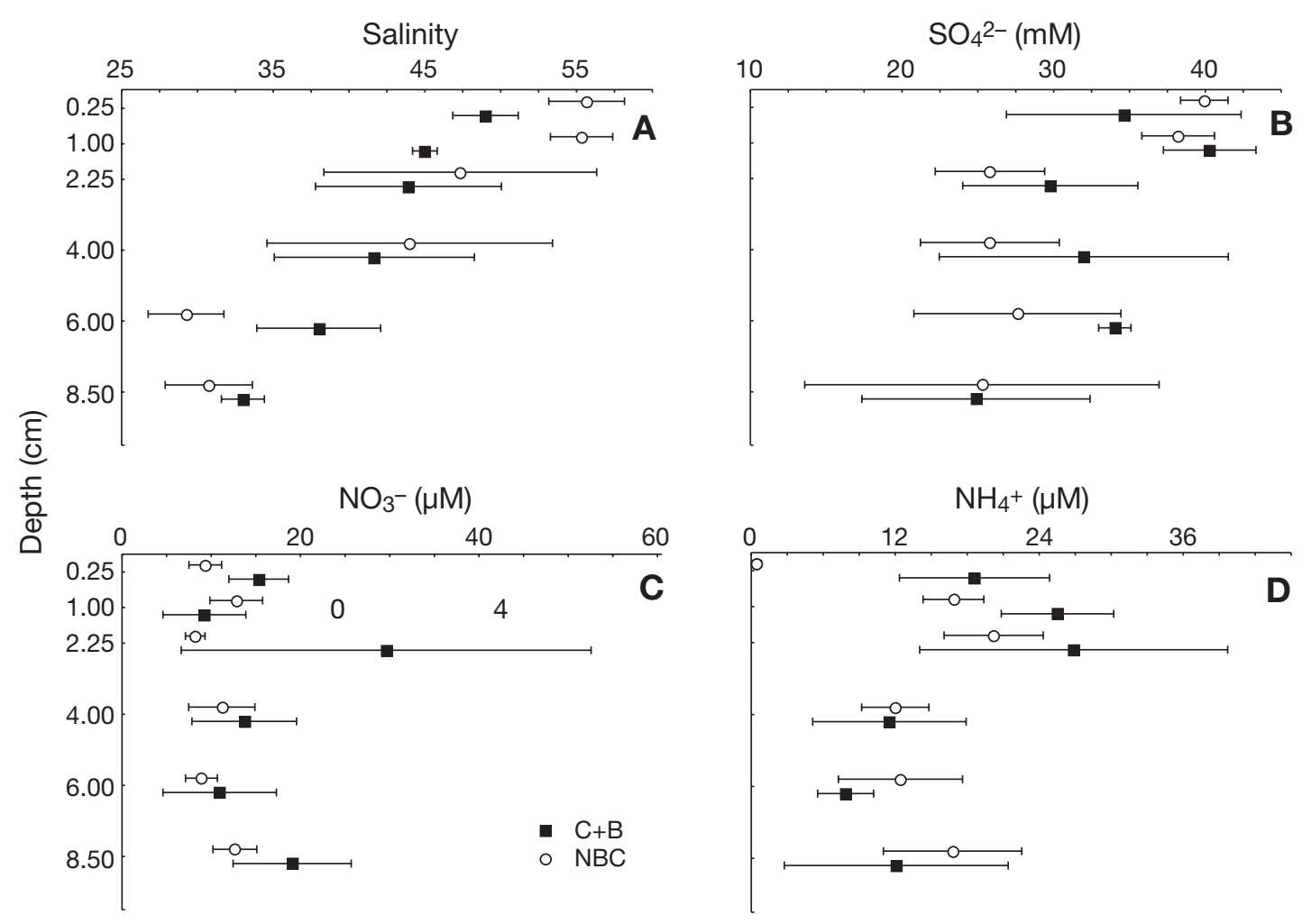

Fig. 3. Vertical pore water profiles of (A) salinity, (B) sulphate concentration, (C) nitrate concentration, and (D) ammonium concentration in $\mathrm{C}+\mathrm{B}$ and NBC experimental treatments (see Table 1 legend)

\section{Effects of Chasmagnathus granulatus burrows on pore water and sediment characteristics}

The salinity was higher in the $\mathrm{C}+\mathrm{B}$ treatment than in the B and NBC treatments and did not show differences with depth in any treatment (Treatment: $F_{2,54}=$ 9.49, p < 0.05; Fig. 6A). Sulphate concentration showed interaction effects between treatment and depth (Treatment $\times$ Depth: $F_{10,54}=7.11, \mathrm{p}<0.05$; Fig. 6B). An a posteriori LSD test showed that the sulphate concen- tration was higher for the $\mathrm{C}+\mathrm{B}$ treatment on the surface layers. However, there were no differences in the deeper layers. Pore water nitrate concentration differed among the 3 treatments for different depth intervals, showing interaction effects (Treatment $\times$ Depth: $F_{10,54}=3.10, \mathrm{p}<0.05$; Fig. $6 \mathrm{C}$ ). The highest nitrate concentration was in the 0.5 to $1.5 \mathrm{~cm}$ depth interval for $\mathrm{C}+\mathrm{B}$ treatments and, in general, the nitrate concentration was higher in this bioturbated treatment than in NBC and B treatments. In the NBC treatment, nitrate
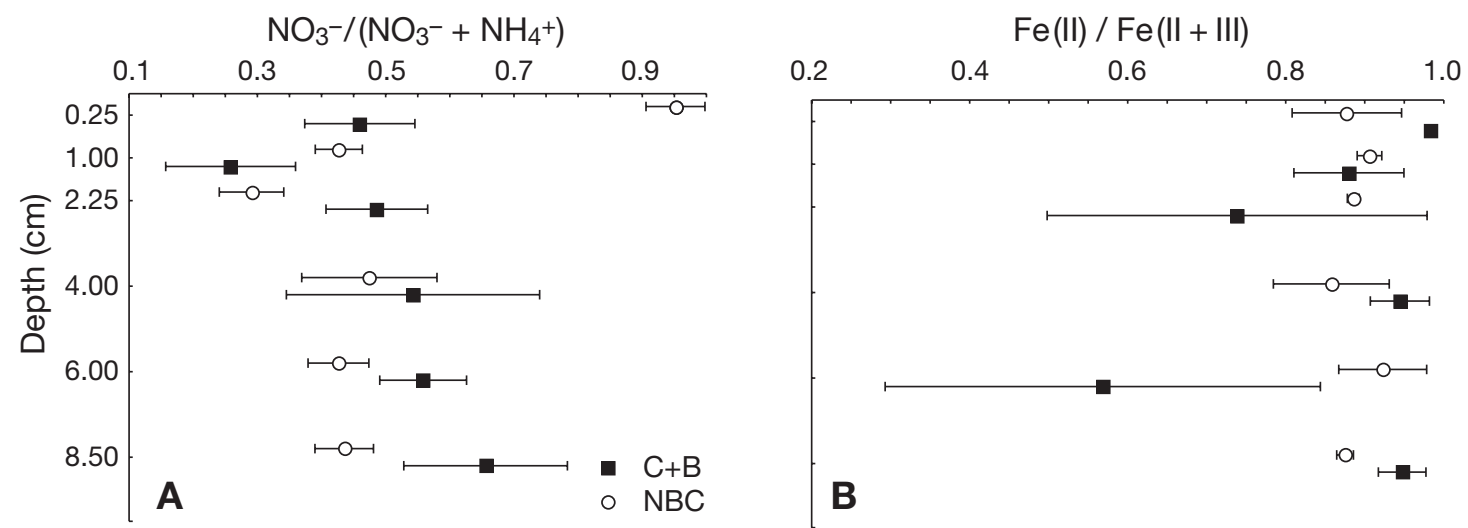

Fig. 4. Depth profiles of (A) $\mathrm{NO}_{3}{ }^{-} /\left(\mathrm{NO}_{3}{ }^{-}+\mathrm{NH}_{4}{ }^{+}\right)$ratio, and (B) $\mathrm{Fe}(\mathrm{II}) / \mathrm{Fe}(\mathrm{II}+\mathrm{III})$ ratio in $\mathrm{C}+\mathrm{B}$ and NBC treatments (see Table 1 legend) 

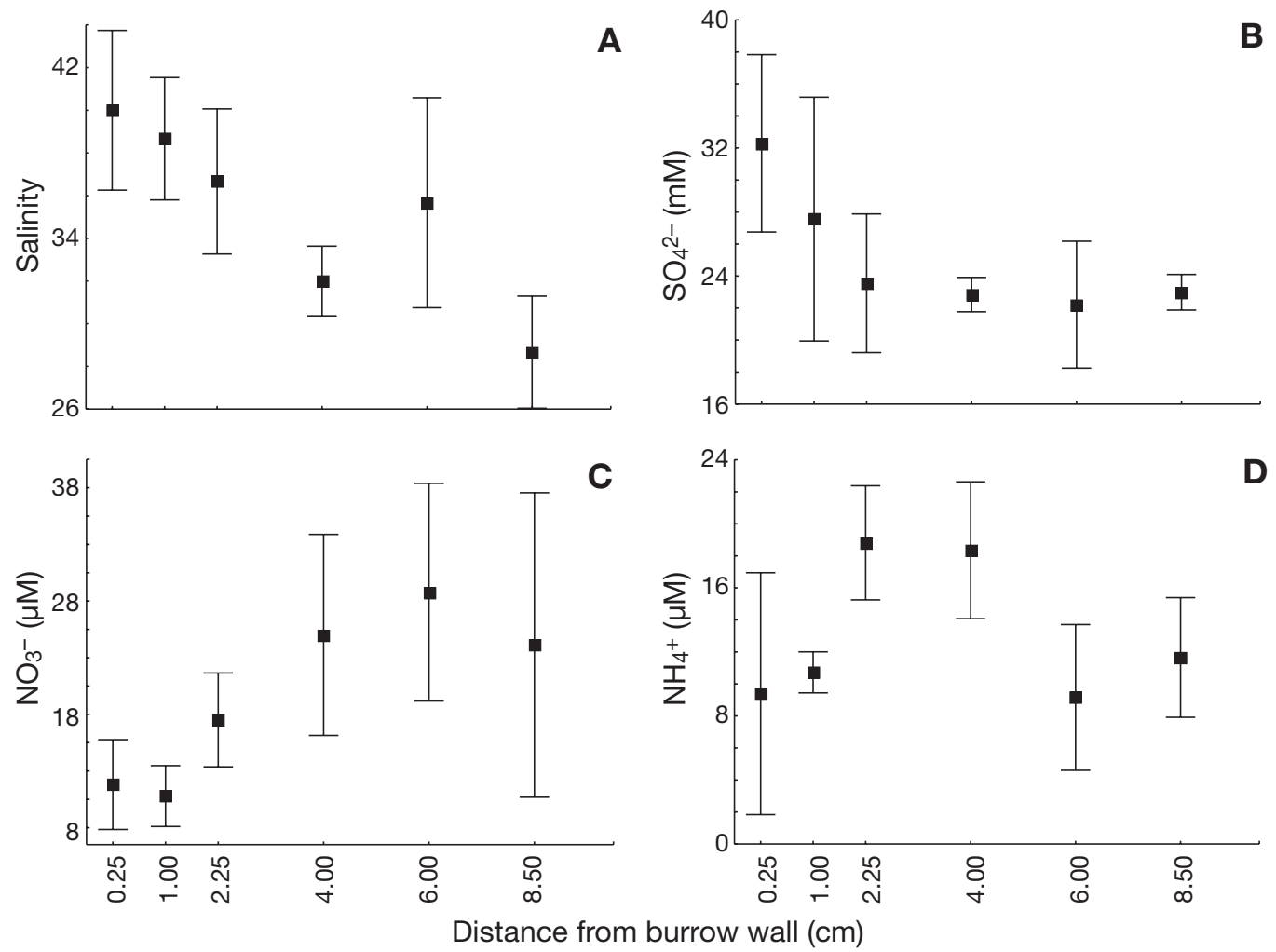

Fig. 5. Radial pore water profiles of (A) salinity, (B) sulphate concentration, (C) nitrate concentration, and (D) ammonium concentration in $\mathrm{C}+\mathrm{B}$ experimental treatment (see Table 1 legend)

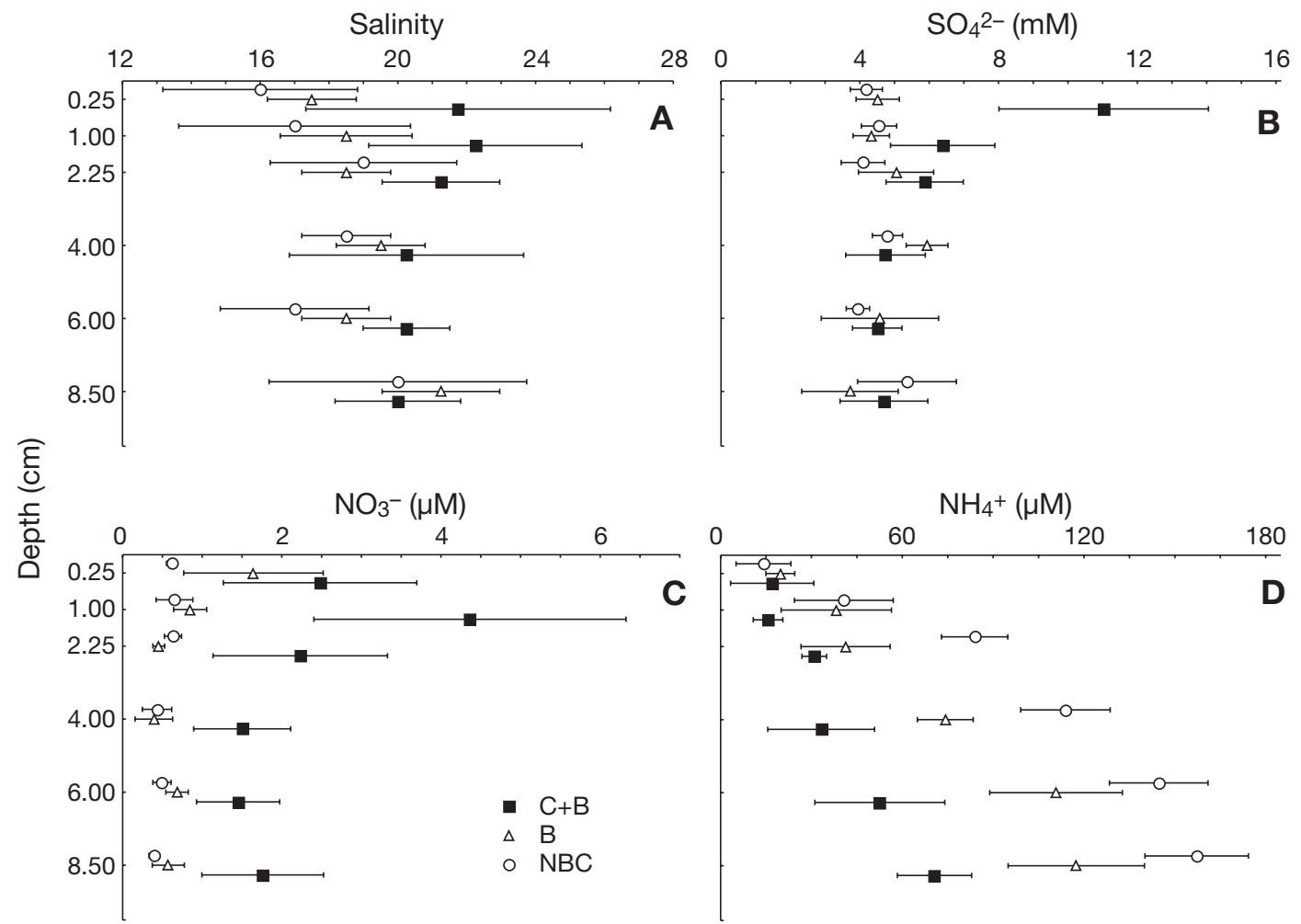

Fig. 6. Vertical pore water profiles of (A) salinity, (B) sulphate concentration, (C) nitrate concentration, and (D) ammonium concentration in $\mathrm{C}+\mathrm{B}, \mathrm{B}$ and NBC experimental treatments (see Table 1 legend) 
concentration was lower for the whole profile, while in the B treatment, nitrate concentration was higher in the upper sediment layer. The ammonium concentration differed among the 3 treatments and showed an interaction between the factors (Treatment $\times$ Depth: $F_{10,54}=7.09, \mathrm{p}<0.05$; Fig. 6D). The ammonium concentration was lower in the first depth interval for all treatments, but at deeper intervals the ammonium concentration was lower in $\mathrm{C}+\mathrm{B}$ treatments than in the $\mathrm{B}$ and NBC treatments. Eh differed among the 3 treatments, showing an interaction between the factors (Treatment $\times$ Depth: $F_{10,72}=3.16, \mathrm{p}<0.05$; Fig. 7). Eh was higher (oxic conditions) in the first depth interval for all treatments, and was higher in bioturbated treatments $(\mathrm{C}+\mathrm{B})$ in deeper layers. Differences were larger between treatments without crabs (NBC and B treatments) than between $\mathrm{C}+\mathrm{B}$ and $\mathrm{B}$ treatments. Eh around the burrows in the $\mathrm{C}+\mathrm{B}$ and $\mathrm{B}$ treatment varied with burrow distance (Treatment: $F_{1,48}=36.84, \mathrm{p}<0.05$; Distance: $F_{5,48}=221.10, \mathrm{p}<0.05$; Fig. 8). In the $\mathrm{C}+\mathrm{B}$ treatments,

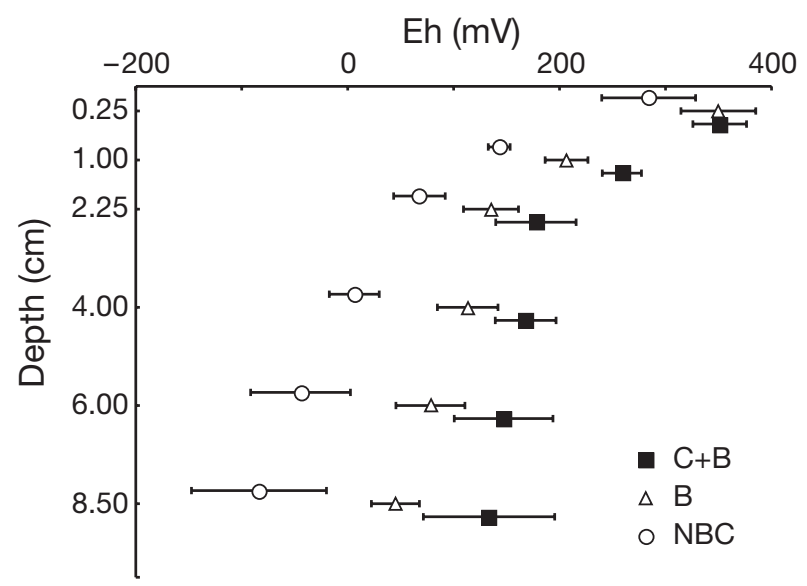

Fig. 7. Vertical redox profiles in $\mathrm{C}+\mathrm{B}, \mathrm{B}$ and NBC experimental treatments (see Table 1 legend)

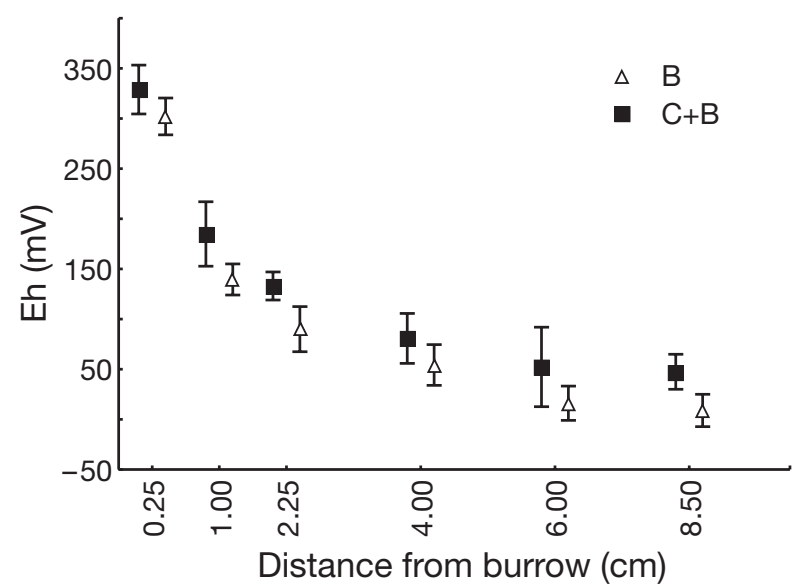

Fig. 8. Radial redox profiles in $\mathrm{C}+\mathrm{B}$ and $\mathrm{B}$ treatments (see Table 1 legend) the redox potential was higher than in the B treatment. In both treatments the sediment was oxic in the 1st sections (0 to $1.5 \mathrm{~cm}$ ), and became more reduced as the distance from the burrow wall increased.

\section{Effect of Chasmagnathus granulatus on transport of particulate material in sediment column}

The number of microspheres per sediment gram differed significantly for both treatment and depth, showing an interaction between the factors (Treatment $x$ Depth: $F_{5,48}=16.40, \mathrm{p}<0.05$; Fig. 9). An a posteriori LSD test showed that microsphere content was similar for both treatments on the surface layer. However, in the deeper layers the microsphere content in the nocrab treatment was noticeably lower than in the crab treatment.

The bioturbation coefficient differed for each treatment ( $t$-test: $t=10.98, \mathrm{df}=4, \mathrm{p}<0.001$ ). In the crab treatment it was $>15 \times$ higher $\left(D_{\mathrm{B}} \pm \mathrm{SD}=251 \pm 47 \mathrm{~cm}^{2}\right.$ $\left.\mathrm{yr}^{-1}\right)$ than in the no-crab treatment $\left(D_{\mathrm{B}} \pm \mathrm{SD}=15 \pm\right.$ $\left.6 \mathrm{~cm}^{2} \mathrm{yr}^{-1}\right)$.

\section{DISCUSSION}

Our results show that the activity of Chasmagnathus granulatus and its burrows have important effects on pore water chemical characteristics in marsh sediments. C. granulatus affects the transport of particulate material in the sediment column, mixing the upper layers of sediments within a few days. Also, crab activities enhance the content of dissolved inorganic nitrogen (DIN) and change solute distribution in the sediment column pore water. Redox potential of sediments

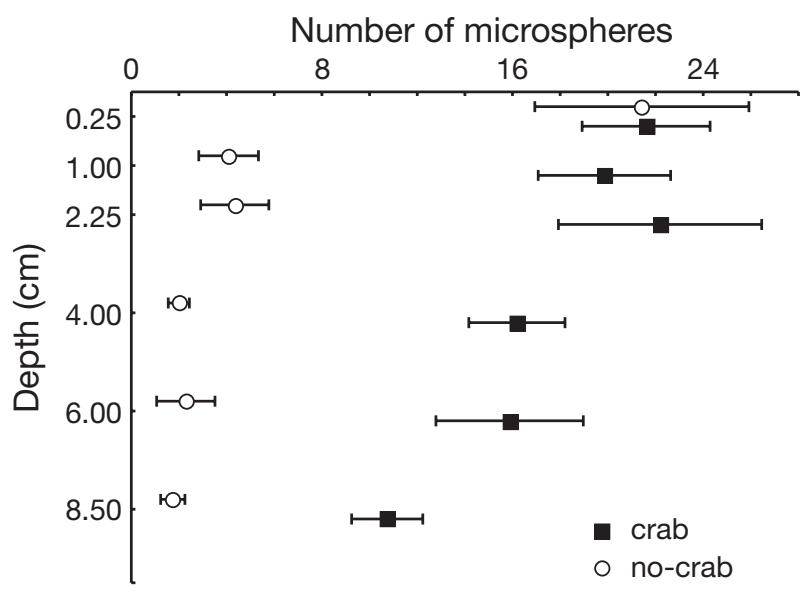

Fig. 9. Microsphere redistribution as a result of bioturbating activities of Chasmagnathus granulatus 
with bioturbation activities is higher than in sediments without bioturbation, revealing that bioturbation produces more oxic conditions. Our experiments show that the presence and activity of this crab have greater effects than does the presence of its burrows only.

Pore water characteristics in bioturbated and nonbioturbated natural areas differ from those observed in the experimental results. However, if pore water profiles from natural areas are corrected for salinity, this inconsistency disappears. Corrected pore water profiles from natural areas are in close agreement with the profiles obtained in the exclusion experiment conducted to evaluate the effect of crab activities on pore water characteristics. Both natural and experimental profiles revealed an important effect of evaporation, which was not present in the second experiment. The difference may be associated with the high temperature and low level of rainfall at the time of sampling in natural areas during the first experiment. Furthermore, aeration may enhance coupled nitrificationdenitrification by increasing the availability of $\mathrm{O}_{2}$ and thereby stimulating aerobic ammonium oxidation (Rysgaard et al. 1994). Thus, these extreme environmental conditions that generate the drying and aeration of the sediments are probably responsible for the lower ammonium concentrations (released by aerobic oxidation, see Qiu \& McComb 1996) in sediments in comparison with those of the second experiment.

Surface sediment with or without bioturbation is typically oxic (Fenchel et al. 1998, our results). Bioturbated sediments retain higher Eh values than do non-bioturbated sediments (without crabs or burrows, or only with unoccupied burrows), and Eh values reveal that sulphidic conditions are reached rapidly as depth increases. However, the interaction between depth and sediment type indicates that bioturbation not only affects Eh values, but also the shape of Eh depth profiles (i.e. in comparison with non-bioturbated sediments, the increase in Eh is greater at depth than at the surface of bioturbated sediments). Eh values around occupied and unoccupied burrows exhibited a similar pattern. These results indicate that Chasmagnathus granulatus directly (bioturbation) and indirectly (burrow structures) enhanced sediment oxygenation. Thus, crabs may favor the growth and productivity of salt marsh vegetation (see Bortolus et al. 2002, 2004) by reducing sediment sulphide production, which may be toxic for benthic fauna (Herman et al. 1999) and vegetation (Bradley \& Morris 1992), and by enhancing oxygen availability. The ratio between the enhancement of area and volume of sediment occupied by burrows (optimizing exchange area and sediment availability, Fig. 1D) suggests that crabs are producing a larger positive effect in marsh sediments. At these sites, the presence of crabs is facilitated by the presence of plants (Bortolus et al. 2002); crab burrows also have large positive effects on plants (Bortolus et al. 2002) owing to the reduction in anoxia during flooding periods.

Previous research has demonstrated the influence of other bioturbating organisms, such as polychaetes and other crabs, on microbial activities (Aller 1994), physical-chemistry characteristics (Kostka et al. 2002) and nutrient cycles in marsh sediments. Nevertheless, until now, the impact of large bioturbators like Chasmagnathus granulatus has received little attention (Ziebis et al. 1996). For example, the burrows of the fiddler crab Uca pugnax are of 5 to $25 \mathrm{~cm}$ depth with densities of 224 to 480 burrow $\mathrm{m}^{-2}$, increasing sediment Eh and continuously mixing the upper 2 to $3 \mathrm{~cm}$ of sediment (Bertness 1985), and enhancing particle transport and sediment-water exchange through their activities (Kristensen 1985). Similarly, C. granulatus completely mixes the upper 7 to $10 \mathrm{~cm}$ of sediment in a period of $30 \mathrm{~d}$ (our results). The bioturbation coefficient for Mar Chiquita sediments $\left(250 \mathrm{~cm}^{2} \mathrm{yr}^{-1}\right)$ is low in comparison with estimates for $U$. pugnax-bioturbated sediments $\left(\sim 1000 \mathrm{~cm}^{2} \mathrm{yr}^{-1}\right)$. However, the $D_{\mathrm{B}}$ of our sites is similar to that reported for tidal flats bioturbated by Macoma balthica (Paalberg et al. 2005), and is high in comparison with the 0.2 to $150 \mathrm{~cm}^{2} \mathrm{yr}^{-1}$ estimated for polychaete-bioturbated sediments (Wheatcroft 1992, Berg et al. 2003). The high degree of reworking produced by this crab has a large effect on the transport of electron acceptors and OM, and thus stimulates organic carbon mineralization. The model-calculated net OM degradation rate is much greater in bioturbated $(\mathrm{kG}=$ $10.6 \pm 6.1 \mu \mathrm{M} \mathrm{s}^{-1}$ ) than in non-bioturbated sediments $\left(\mathrm{kG}=4.9 \pm 17.8 \mu \mathrm{M} \mathrm{s}^{-1}\right.$ if there were unoccupied burrows present; and $\mathrm{kG}=0.02 \pm 0.013 \mu \mathrm{M} \mathrm{s}^{-1}$ without burrows). Moreover, in non-bioturbated sediment, most OM degradation is restricted to the upper $5 \mathrm{~mm}$ of sediments (oxic layer), while in bioturbated sediments, OM degradation also takes place in deeper sediments (Fig. 10A). Differences between occupied and unoccupied burrows indicate that the higher OM degradation rate is due to both oxygen penetration and to OM (and electron acceptors) transport into deep sediment. Hence, our results show that $C$. granulatus directly (bioturbation) and indirectly (burrow structure) stimulates OM degradation.

Pathways of OM degradation are also affected by Chasmagnathus granulatus activities. The model results also show that the depth-integrated aerobic OM degradation rate is several orders higher in bioturbated sediments $\left(7.8 \times 10^{-5} \mathrm{~mol} \mathrm{~m}^{-2} \mathrm{~s}^{-1}\right.$ with occupied burrows, $2.4 \times 10^{-4} \mathrm{~mol} \mathrm{~m}^{-2} \mathrm{~s}^{-1}$ with unoccupied burrows) than in non-bioturbated sediments $(4.3 \times$ $10^{-11} \mathrm{~mol} \mathrm{~m}^{-2} \mathrm{~s}^{-1}$ ). Furthermore, anaerobic pathways of OM degradation are also stimulated by C. granulatus. 

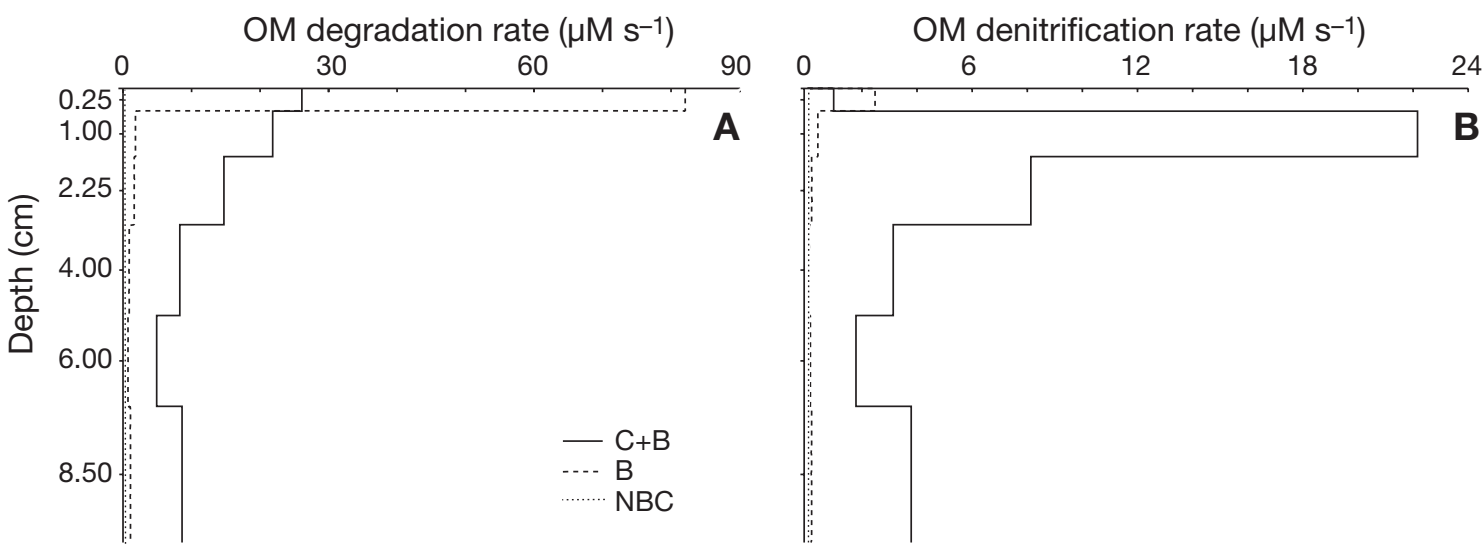

Fig. 10. Model-calculated depth profiles of (A) organic matter (OM) reduction rates, and (B) nitrate consumption rates owing to $\mathrm{OM}$ remineralization for $\mathrm{C}+\mathrm{B}, \mathrm{B}$ and $\mathrm{NBC}$ experimental treatments (see Table 1 legend)

Similar to sediments affected by the polychaete Nereis diversicolor, where nitrification occurs between 0.9 and $1.5 \mathrm{~mm}$ and nitrate reduction occurs in the nitratecontaining deep layers (Nielsen et al. 2004), C. granulatus also affects nitrate concentrations in relation to depth and distance to burrows. Moreover, the interaction between depth and sediment type (i.e. without burrows, with occupied burrows and with unoccupied burrows) for nitrate concentrations indicates that the differences in nitrate concentrations are both depthand sediment-dependent (i.e. nitrate concentration did not differ with depth in non-bioturbated sediments; showed a superficial maxima in sediments with unoccupied burrows; and showed a sub-superficial maxima in sediments with occupied burrows). Model-calculated depth profiles of denitrification rate (Fig. 10B) indicate that most of this process takes place between 1 and 3 $\mathrm{cm}$ depth in bioturbated sites; nevertheless, denitrification is stimulated at all depths. The relative depthintegrated nitrate usage in the OM degradation was several times higher in bioturbated sediments (5.9 and $2.2 \%$ for sediment with occupied and unoccupied burrows respectively) than in non-bioturbated sediments (1.6\% of nitrate utilization). In bioturbated sediment, nitrification is restricted to the upper oxic layer ( 0.5 to $1.5 \mathrm{~cm}$ depth).

Profiles around Chasmagnathus granulatus burrows show similar patterns. If unoccupied burrows are present, denitrification rate is higher in the 0.5 to $1.5 \mathrm{~cm}$ layer than in deep sediment, and nitrification occurs predominantly in the upper $5 \mathrm{~mm}$ of sediment. Pore water ammonium content is lower in bioturbated than in non-bioturbated sediment (even if there are unoccupied burrows present); this pattern is shown in Fig. 4A, where the ratio between oxidized and reduced $\mathrm{N}$ compounds is higher in the bioturbated $\mathrm{C}+\mathrm{B}$ treatments, probably owing to high redox conditions of bioturbated sediments, and also to burrow bioirrigation. The same pattern should occur with extractable $\mathrm{Fe}$; however, owing to the high variability of Fe (III) species, this is not well understood (Fig. 4B). The lower depthintegrated concentration of DIN in bioturbated than in non-bioturbated areas may be due to $\mathrm{N}$ losses by the enhancement of solute flux out of the sediment, as previously found in sediments with polychaete activity (i.e. Nereis diversicolor, Kristensen \& Hansen 1999). Thus, regardless of the contribution of $\mathrm{N}$ by crab excretions and passive deposition into burrows of sediment rich in OM and organic N (Botto et al. 2006), crab burrow walls may act like polychaete burrows, stimulating microbial activity (Kristensen 1985, Nielsen et al. 2004, our results), and enhancing not only the production but also the export of remineralized DIN.

One of most important sources of food for estuaries and oceans derives from estuarine $\mathrm{OM}$, but only a minor fraction of it is exported as organic detritus (Nixon 1980). In estuaries with bioturbated sediments, this could result from passive deposition of particulate OM into burrows (see Botto et al. 2006) or burial into the sediment (Gutiérrez et al. 2006), and also from the high rates of OM degradation that takes place in bioturbated sediments (Kostka et al. 2002, Furukawa et al. 2004, our results). Metabolites and nutrients produced from OM degradation would be consumed in the estuary (supporting the estuarine food web), or be exported to the coastal ocean as dissolved OM and dissolved nutrients. Considering the geographic and local spatial extension of the crab beds (see Iribarne et al. 2005, Botto et al. 2006) and the high densities of Chasmagnathus granulatus, the large size of their burrows and their high rates of sediment removal (Iribarne et al. 1997, Botto \& Iribarne 2000), we expect that their effects on biogeochemical cycles have important consequences at a large scale. The large biogeochemical changes induced by this crab affect the rates and pathways of OM degradation in intertidal sediments, and 
are also expected to have a large effect on microbial processes and nutrients flows to neighboring systems. Similar effects are expected for other estuaries inhabited by any burrowing species (i.e. Callianassa californiensis and Upogebia pugettensis along the west coast of the USA; Posey 1986, Posey et al. 1991) that maintain permanently open burrows.

Acknowledgements. We thank P. Daleo, M. Escapa, A. Mendez Casariego and M. Valiñas for field assistance and F. Botto and M. Escapa for critically reviewing an earlier version of the manuscript. We thank B. Hopkinson and 2 anonymous reviewers for their comments, which greatly improved the manuscript. This project was supported by the UNMdP, the IFS (Sweden; A2501-2F), the Fundación Antorchas (Argentina; 13900-13), ANPCyT and CONICET (Argentina PIP2851), all granted to O.I. This study forms part of E.F.'s PhD thesis at UNMdP; E.F. was supported by a doctoral scholarship from CONICET (Argentina).

\section{LITERATURE CITED}

Aller RC (1994) Bioturbation and remineralization of sedimentary organic matter: effects of redox oscillation. Chem Geol 114:331-345

Alongi DM (1998) Coastal ecosystem processes. CRC Press, Boca Raton, FL

Berg P, Rysgaard S, Thamdrup B (2003) Dynamic modeling of early diagenesis and nutrient cycling. A case study in an Arctic marine sediment. Am J Sci 303:905-955

Bertness MD (1985) Fiddler crab regulation of Spartina alterniflora production on a New England salt marsh. Ecology 66: 1042-1055

Bortolus A (2006) The austral cordgrass Spartina densiflora Brong.: its taxonomy, biogeography and natural history. J Biogeogr 33:158-168

Bortolus A, Schwint E, Iribarne O (2002) Positive plant-animal interactions in a high marsh of a Southwestern Atlantic coastal lagoon. Ecology 83:733-742

Bortolus A, Laterra P, Iribarne O (2004) Crab-mediated phenotypic changes in Spartina densiflora Brong. Estuar Coast Shelf Sci 59:97-107

Boschi EE (1964) Los crustáceos decápodos Brachyura del litoral bonaerense (R. Argentina). Bol Inst Biol Mar Mar del Plata 6:1-99

Botto F, Iribarne O (2000) Contrasting effects of two burrowing crabs (Chasmagnathus granulata and Uca uruguayensis) on sediment composition and transport in estuarine environments. Estuar Coast Shelf Sci 51:141-151

Botto F, Valiela I, Iribarne O, Martinetto P, Alberti J (2005) Impact of burrowing crabs on $\mathrm{C}$ and $\mathrm{N}$ sources, control, and transformations in sediments and food webs of SW Atlantic estuaries. Mar Ecol Prog Ser 293:155-164

Botto F, Iribarne O, Gutierrez J, Bava J, Gagliardini A, Valiela I (2006) Ecological importance of passive deposition of organic matter into burrows of the SW Atlantic crab Chasmagnathus granulatus. Mar Ecol Prog Ser 312: 201-210

Boudreau BP (1997) Diagenetic models and their implementation: modelling transport and reaction in aquatic sediments. Springer, Berlin

Boudreau BP, Mucci A, Sundby B, Luther GW, Silverberg N (1998) Comparative diagenesis at three sites on the Canadian continental margin. J Mar Res 56:1259-1284
Bradley PM, Morris JT (1992) Effect of salinity on the critical nitrogen concentration of Spartina alterniflora Loisel. Aquat Bot 43:149-161

Escapa M, Iribarne O, Navarro D (2004) Effects of intertidal burrowing crab Chasmagnathus granulatus on infaunal zonation patterns, tidal behavior and risk of mortality. Estuaries 27:120-131

Fasano JL, Hernandez MA, Isla FI, Schnack EJ (1982) Aspectos evolutivos y ambientales de la laguna Mar Chiquita (provincia de Buenos Aires, Argentina). Oceanol Acta 4(Suppl):285-292

Fenchel T, King GM, Blackburn TH (1998) Bacterial biogeochemistry: the ecophysiology of mineral cycling. Academic Press, San Diego, CA

Furukawa Y, Smith A, Kostka J, Watkins J, Alexander C (2004) Quantification of macrobenthic effects ondiagenesis using a multicomponent inverse model in salt marsh sediments. Limnol Oceanogr 49:2058-2072

Gutiérrez JL, Jones CG, Groffman PM, Findlay SEG, Iribarne OO, Ribeiro PD, Bruschetti CM (2006) The contribution of crab burrow excavation to carbon availability in surficial salt-marsh sediments. Ecosystems 9:647-658

Herman PMJ, Middelburg JJ, Van de Koppel J, Heip CHR (1999) Nutrients in estuaries. In: Nedwell DB, Raffaelli DG (eds) Advances in ecological research: estuaries. Academic Press, San Diego, CA, p 195-240

Iribarne O, Bortolus A, Botto F (1997) Between-habitat differences in burrow characteristics and trophic modes in the southwestern Atlantic burrowing crab Chasmagnathus granulata. Mar Ecol Prog Ser 155:137-145

Iribarne O, Botto F, Martinetto P, Gutiérrez J (2000) The role of the SW Atlantic burrowing crab in sequestering debris. Mar Pollut Bull 40:1057-1062

Iribarne O, Bruschetti M, Escapa M, Bava J and 6 others (2005) Small- and large-scale effect of the SW Atlantic burrowing crab Chasmagnathus granulatus on habitat use by migratory shorebirds. J Exp Mar Biol Ecol 315:87-101

Korestky CM, Meile C, Van Cappellen P (2002) Quantifying bioirrigation using ecological parameters: a stochastic approach. Geochem Trans 3:17-30

Kostka JE, Gribsholt B, Petrie E, Dalton D, Skelton H, Kristensen $\mathrm{E}$ (2002) The rates and pathways of carbon oxidation in bioturbated saltmarsh sediments. Limnol Oceanogr 47:230-240

Kristensen E (1985) Oxygen and inorganic nitrogen exchange in a Nereis virens (Polychaeta) bioturbated sedimentwater system. J Coast Res 1:109-116

Kristensen E, Hansen K (1999) Transport of carbon dioxide and ammonium in bioturbated (Nereis diversicolor) coastal marine sediments. Biogeochemistry 45:147-168

Mackin JE, Aller RC (1984) Ammonium adsorption in marine sediments. Limnol Oceanogr 29:250-257

Martinetto P, Iribarne O, Palomo G (2005) Effect of fish predation on intertidal benthic fauna is modified by crab bioturbation. J Exp Mar Biol Ecol 318:71-84

Meysman FJR, Galaktionov OS, Madani S, Middelburg JJ (2005) Modelling biological interactions in aquatic sediments as coupled reactive transport. In: Kristensen E, Haese RR, Kostka JE (eds) Interactions between macroand microorganisms in marine sediments. American Geophysical Union, Washington, DC, p 359-388

Nedwell DB, Jickells TD, Trimmer M, Sanders R (1999) Nutrients in estuaries. In: Nedwell DB, Raffaelli DG (eds) Advances in ecological research: estuaries. Academic Press, San Diego, CA, p 43-92

Nielsen OI, Gribsholt B, Kristensen E, Revsbech NP (2004) Microscale distribution of oxygen and nitrate in sediment 
inhabited by Nereis diversicolor: spatial patterns and estimated reaction rates. Aquat Microb Ecol 34:23-32

Nixon SW (1980) Between coastal marshes and coastal waters - a review of twenty years of speculation and research on the role of salt marshes and coastal waters in estuarine productivity and water chemistry. In: Hamilton $\mathrm{P}$, McDonald KB (eds) Estuarine and wetland processes with emphasis on modeling. Plenum Press, New York, p 437-526

Paarlberg AJ, Knaapen MAF, de Vries MB, Hulscher SJMH, Wang ZB (2005) Biological influences on morphology and bed composition of an intertidal flat. Estuar Coast Shelf Sci 64:577-590

Posey MH (1986) Changes in a benthic community associated with dense beds of a burrowing deposit-feeder, Callianassa californiensis. Mar Ecol Prog Ser 31:15-22

Posey MH, Dumbauld BR, Armstrong DA (1991) Effects of a burrowing mud shrimp, Upogebia pugettensis (Dana), on abundances of macro-infauna. J Exp Mar Biol Ecol 148: 283-294

Qiu S, McComb AJ (1996) Drying-induced stimulation of ammonium release and nitrification in reflooded lake sediment. Mar Freshw Res 47:531-536

Revsbech NP, Sørensen J, Blackburn TH (1980) Distribution of oxygen in marine sediments measured with microelectrodes. Limnol Oceanogr 25:403-411

Rozema J, Leendertse P, Bakker J, van Wijnen H (2000)

Editorial responsibility: Lisa Levin (Contributing Editor), La Jolla, California, USA
Nitrogen and vegetation dynamics in European salt marshes. In: Weintein MP, Kreeger DA (eds) Concepts and controversies in tidal marsh ecology. Kluwer Academic Publishers, Dordrecht, p 469-491

Rysgaard S, Risgaard-Petersen N, Sloth NP, Jensen K, Nielsen LP (1994) Oxygen regulation of nitrification and denitrification in sediments. Limnol Oceanogr 39:1643-1652

Schlesinger WH (1991) Biogeochemistry: an analysis of global change. Academic Press, San Diego, CA

Solórzano L (1969) Determination of ammonia in natural waters by the phenolhypochlorite method. Limnol Oceanogr 14:799-801

Tamura H, Goto K, Yotsuyanagi T, Nagayama M (1974) Spectrophotometric determination of iron(II) with 1,10-phenanthroline in the presence of large amounts of iron(III). Talanta 21:314-318

Underwood AJ (1997) Experiments in ecology: their logical design and interpretation using analysis of variance. Cambridge University Press, Cambridge

Wheatcroft RA (1992) Experimental test for particle sizedependent bioturbation in the deep ocean. Limnol Oceanogr 37:90-104

Zar JH (1999) Biostatistical analysis, 3rd edn. Prentice-Hall, Englewood Cliffs, NJ

Ziebis W, Forster S, Huettel M, Jørgensen BB (1996) Complex burrows of the mud shrimp Callianassa truncata and their geochemical impact in the sea bed. Nature 382:619-622

Submitted: March 7, 2006; Accepted: January 2, 2007 Proofs received from author(s): June 22, 2007 